\title{
Price-Setting Mixed Duopoly Models with Complementary Goods
}

\author{
Kazuhiro Ohnishi \\ Institute for Basic Economic Science, Osaka, Japan \\ E-mail:ohnishi@e.people.or.jp \\ Received March 4, 2010; revised March 25, 2010; accepted April 5, 2010
}

\begin{abstract}
This paper considers domestic (resp. international) Bertrand mixed duopoly competition in which a stateowned welfare-maximizing public firm and a domestic (resp. foreign) profit-maximizing private firm produce complementary goods. The main purpose of the paper is to present and to compare the equilibrium outcomes of the two mixed duopoly models.
\end{abstract}

Keywords: Complementary Goods, Price Competition, Domestic Mixed Duopoly, International Mixed Duopoly

\section{Introduction}

The analysis of mixed market models that incorporate state-owned welfare-maximizing public firms has received considerable attention in recent years and has been widely performed by many researchers. However, most studies consider quantity competition, such as [1-16]. ${ }^{1}$

Some studies consider mixed markets with price competition, such as [22-26]. These studies examine pricesetting mixed market models with domestic firms and do not include foreign firms. Ohnishi [27] considers an international mixed market in which a state-owned public firm competes on price with a foreign private firm. However, this study examines mixed duopoly competition in which public and foreign private firms produce imperfectly substitutable goods. To the best of my knowledge, the analysis of international Bertrand mixed markets with public and foreign private firms producing complementary goods has been ignored.

Therefore, we analyze the behavior of a state-owned public firm and a foreign private firm in an international price-setting model with complementary goods. We consider both domestic and international mixed duopoly models with complementary goods. The main purpose of this paper is to present and to compare the equilibrium outcomes of the two mixed duopoly models.

The remainder of the paper proceeds as follows. In Section 2, we formulate a domestic Bertrand mixed duopoly model in which a state-owned public firm and a domestic private firm produce complementary goods. We

${ }^{1}$ See, for example, [17-21] for excellent surveys. show the slope of each firm's reaction curve in the domestic Bertrand mixed duopoly model with complementary goods. We present the equilibrium outcome of the domestic Bertrand mixed duopoly model with complementary goods. Section 3 analyzes the equilibrium outcome of an international Bertrand model in which a state-owned public firm and a foreign private firm produce complementary goods. Section 4 compares the equilibrium outcomes of the two mixed duopoly models. Finally, Section 5 concludes the paper.

\section{Domestic Mixed Duopoly with Complementary Goods}

In this section, we consider a market in which one stateowned welfare-maximizing public firm and one domestic profit-maximizing private firm produce complementary goods. The basic structure is from Bárcena-Ruiz [25]. In the remainder of this paper, subscripts $\mathrm{S}$ and $\mathrm{D}$ denote the state-owned firm and the domestic private firm, respectively. There is no possibility of entry or exit. On the consumption side, there is a continuum of consumers of the same type whose utility function is linear. The representative consumer maximizes $U\left(q_{\mathrm{S}}, q_{\mathrm{D}}\right)-p_{\mathrm{S}} q_{\mathrm{S}}-p_{\mathrm{D}} q_{\mathrm{D}}$, where $q_{i}$ is the amount of good $i$ and $p_{i}$ is its price $(i=\mathrm{S}, \mathrm{D})$. The function $U\left(q_{\mathrm{S}}, q_{\mathrm{D}}\right)$ is quadratic, strictly concave and symmetric in $q_{\mathrm{S}}$ and $q_{\mathrm{D}}: U\left(q_{\mathrm{S}}, q_{\mathrm{D}}\right)=$ $a\left(q_{\mathrm{S}}+q_{\mathrm{D}}\right)-\left(q_{\mathrm{S}}^{2}-q_{\mathrm{S}} q_{\mathrm{D}}+q_{\mathrm{D}}^{2}\right) / 2$, where $a>0$. The de- 
mand function is given by

$$
q_{i}=\frac{2\left(3 a-2 p_{i}-p_{j}\right)}{3} \quad(i, j=\mathrm{S}, \mathrm{D} ; i \neq j) .
$$

Each firm's profit function is given by

$$
\pi_{i}=\left(p_{i}-c\right) q_{i} \quad(i=\mathrm{S}, \mathrm{D}),
$$

where $c>0$ is the total cost for each unit of output. We assume $c<a$ to assure that the production levels of firms are positive. Domestic social welfare, which is the sum of consumer surplus $(C S)$ and profits, is given by

$$
W=C S+\pi_{\mathrm{S}}+\pi_{\mathrm{D}} .
$$

From (2) and (3), we derive the following reaction functions in prices:

$$
\begin{aligned}
& R_{\mathrm{S}}=\frac{3 c-p_{\mathrm{D}}}{2}, \\
& R_{\mathrm{D}}=\frac{3 a+2 c-p_{\mathrm{S}}}{4} .
\end{aligned}
$$

From (4) and (5), we can state the following:

Lemma 1. In the domestic Bertrand mixed market with complementary goods, each firm's reaction function is downward sloping.

From (4) and (5), the equilibrium can be derived as follows:

$$
\begin{aligned}
& p_{\mathrm{S}}=\frac{10 c-3 a}{7}, \\
& p_{\mathrm{D}}=\frac{6 a+c}{7}, \\
& q_{\mathrm{S}}=2(a-c), \\
& q_{\mathrm{D}}=\frac{8(a-c)}{7} .
\end{aligned}
$$

Furthermore, the profits and consumer surplus can be expressed as follows:

$$
\begin{aligned}
& \pi_{\mathrm{S}}=\frac{6(a-c)(c-a)}{7}, \\
& \pi_{\mathrm{D}}=\frac{48(a-c)^{2}}{49}, \\
& C S=\frac{37(a-c)^{2}}{49} .
\end{aligned}
$$

From (10), we see that the state-owned firm's profit is negative. Substituting (10), (11) and (12) into (3), social welfare is obtained as

$$
W=\frac{43(a-c)^{2}}{49} .
$$

From (12) and (13), we see that though the state-owned firm's profit is negative, social welfare is higher than consumer surplus.

\section{International Mixed Duopoly with Complementary Goods}

In this section, we consider a market in which one stateowned welfare-maximizing public firm and one foreign profit-maximizing private firm produce complementary goods. In the remainder of this paper, subscript F denotes the foreign private firm. The utility, demand, and profit functions are the same as those of the previous section. Domestic social welfare, which is the sum of consumer surplus and the state-owned firm's profit, is given by

$$
W=C S+\pi_{\mathrm{s}} .
$$

From (2) and (14), we derive the following best response:

$$
\begin{aligned}
& R_{\mathrm{S}}=c, \\
& R_{\mathrm{F}}=\frac{3 a+2 c-p_{\mathrm{S}}}{4} .
\end{aligned}
$$

From (15), we can state the following:

Lemma 2. In the international Bertrand mixed market with complementary goods, the slope of the state-owned firm's reaction curve is zero.

It is shown in Ohnishi [27] that the slope of the state-owned firm's reaction curve is zero in international Bertrand mixed duopoly competition with imperfect substitutable goods. From (15), we see that the result of international Bertrand mixed duopoly competition with complementary goods is similar to that of international Bertrand mixed duopoly competition with imperfect substitutable goods.

From (15) and (16), the equilibrium can be derived as follows:

$$
\begin{aligned}
& p_{\mathrm{S}}=c, \\
& p_{\mathrm{F}}=\frac{3 a+c}{4}, \\
& q_{\mathrm{S}}=\frac{3(a-c)}{2}, \\
& q_{\mathrm{F}}=a-c .
\end{aligned}
$$

From (17), we know that the state-owned firm produces an output such that price equals marginal cost. From (19) and (20), we see that the state-owned firm's output is higher than the foreign private firm's output.

Furthermore, the profits, consumer surplus, and social welfare can be expressed as follows:

$$
\begin{aligned}
& \pi_{\mathrm{S}}=0, \\
& \pi_{\mathrm{F}}=\frac{3(a-c)^{2}}{4},
\end{aligned}
$$




$$
\begin{gathered}
C S=\frac{7(a-c)^{2}}{8}, \\
W=\frac{7(a-c)^{2}}{8} .
\end{gathered}
$$

We see that since the state-owned firm's profit is zero, social welfare is equal to consumer surplus.

\section{Comparisons}

In this section, we begin by presenting comparative statics results. In the remainder of this paper, superscripts $\mathrm{H}$ and I denote the domestic and international mixed duopolies, respectively. We have the following results.

$$
\begin{gathered}
\frac{\partial p_{\mathrm{S}}^{\mathrm{H}}}{\partial a}<0, \frac{\partial p_{\mathrm{D}}^{\mathrm{H}}}{\partial a}>0, \frac{\partial q_{\mathrm{S}}^{\mathrm{H}}}{\partial a}>0, \frac{\partial q_{\mathrm{D}}^{\mathrm{H}}}{\partial a}>0, \\
\frac{\partial p_{\mathrm{S}}^{\mathrm{I}}}{\partial a}=0, \frac{\partial p_{\mathrm{F}}^{\mathrm{I}}}{\partial a}>0, \frac{\partial q_{\mathrm{S}}^{\mathrm{I}}}{\partial a}>0, \frac{\partial q_{\mathrm{F}}^{\mathrm{I}}}{\partial a}>0 .
\end{gathered}
$$

In each model, a rise in a raises the private firm's price. However, in the domestic mixed duopoly model, a rise in a lowers the state-owned firm's price, and in the international mixed duopoly model, a rise in $a$ has no influence on the state-owned firm's price. Furthermore, we have

$$
\begin{gathered}
\frac{\partial p_{\mathrm{S}}^{\mathrm{H}}}{\partial c}>0, \frac{\partial p_{\mathrm{D}}^{\mathrm{H}}}{\partial c}>0, \frac{\partial q_{\mathrm{S}}^{\mathrm{H}}}{\partial c}<0, \frac{\partial q_{\mathrm{D}}^{\mathrm{H}}}{\partial c}<0, \\
\frac{\partial p_{\mathrm{S}}^{\mathrm{I}}}{\partial c}>0, \frac{\partial p_{\mathrm{F}}^{\mathrm{I}}}{\partial c}>0, \frac{\partial q_{\mathrm{S}}^{\mathrm{I}}}{\partial c}<0, \frac{\partial q_{\mathrm{F}}^{\mathrm{I}}}{\partial c}<0 .
\end{gathered}
$$

A rise in $c$ raises the firms' prices and decreases their outputs. We see that the comparative statics results are almost the same in both models.

We now compare the equilibrium outcomes of the two models. The main result of this study is described by the following proposition.

Proposition 1. In the equilibrium outcomes of the domestic and international mixed duopoly models, 1) $\left.\left.\pi_{\mathrm{S}}^{\mathrm{H}}<\pi_{\mathrm{S}}^{\mathrm{I}} ; 2\right) \pi_{\mathrm{D}}^{\mathrm{H}}>\pi_{\mathrm{F}}^{\mathrm{I}} ; 3\right) C S^{\mathrm{H}}<C S^{\mathrm{I}}$; and 4) $W^{\mathrm{H}}>W^{\mathrm{I}}$.

Proof. 1) From (21), we see that $\pi_{\mathrm{S}}^{\mathrm{I}}=0$. Furthermore, from $(10)$ and $0<c<a, \pi_{\mathrm{S}}^{\mathrm{H}}$ is negative.

2) From (11), (22) and $0<c<a$, both $\pi_{\mathrm{D}}^{\mathrm{H}}$ and $\pi_{\mathrm{F}}^{\mathrm{I}}$ are positive, and thus

$$
\begin{aligned}
\pi_{\mathrm{D}}^{\mathrm{H}} & =\frac{48}{49}(a-c)^{2} \\
& =\frac{192}{196}(a-c)^{2}>\pi_{\mathrm{F}}^{\mathrm{I}}=\frac{3}{4}(a-c)^{2}=\frac{147}{196}(a-c)^{2}
\end{aligned}
$$

The proofs of 3) and 4) are omitted, since they are the same as the proof of 2). Q.E.D.

Proposition 1 states that consumer surplus is higher in the international mixed duopoly equilibrium than in the domestic mixed duopoly equilibrium.

\section{Conclusions}

We have first considered a domestic Bertrand model in which a state-owned welfare-maximizing public firm and a domestic profit-maximizing private firm produce complementary goods. We have shown that each firm's reaction function is downward sloping in domestic Bertrand mixed duopoly competition with complementary goods. In addition, we have found that the state-owned firm's profit is negative in equilibrium.

Second, we have considered an international Bertrand model in which a state-owned public firm and a foreign private firm produce complementary goods. We have then shown that the slope of the state-owned firm's reaction curve is zero, and so social welfare is equal to consumer surplus.

Third, we have compared the equilibrium outcomes of the two mixed models. We have demonstrated that though the state-owned firm's profit, the private firm's profit, and social welfare are higher in the domestic mixed duopoly equilibrium than in the international mixed duopoly equilibrium, consumer surplus associated with the international mixed duopoly equilibrium exceeds consumer surplus associated with the domestic mixed duopoly equilibrium.

\section{References}

[1] F. Delbono and G. Rossini, "Competition Policy vs Horizontal Merger with Public, Entrepreneurial, and LaborManaged Firms," Journal of Comparative Economics, Vol. 16, No. 2, June 1992, pp. 226-240.

[2] F. Delbono and V. Denicolò, "Regulating Innovative Activity: The Role of Public Firm," International Journal of Industrial Organization, Vol. 11, No. 1, March 1993, pp. 35-48.

[3] L. Nett, "Why Private Firms are More Innovative than Public Firms," European Journal of Political Economy, Vol. 10, No. 4, December 1994, pp. 639-653.

[4] J. Willner, "Welfare Maximization with Endogenous Average Costs," International Journal of Industrial Organization, Vol. 12, No. 3, September 1994, pp. 373-386.

[5] K. Fjell and D. Pal, "A Mixed Oligopoly in the Presence of Foreign Private Firms," Canadian Journal of Economics, Vol. 29, No. 3, August 1996, pp. 737-743.

[6] K. George and M. La Manna, "Mixed Duopoly, Inefficiency, and Public Ownership," Review of Industrial Organization, Vol. 11, No. 6, December 1996, pp. 853-860.

[7] M. D. White, "Mixed Oligopoly, Privatization and Subsidization," Economics Letters, Vol. 53, No. 2, November 
1996, pp. 189-195.

[8] S. Mujumdar and D. Pal, "Effects of Indirect Taxation in a Mixed Oligopoly," Economics Letters, Vol. 58, No. 2, February 1998, pp. 199-204.

[9] D. Pal, "Endogenous Timing in a Mixed Oligopoly," Economics Letters, Vol. 61, No. 2, November 1998, pp. 181-185.

[10] D. Pal and M. D. White, "Mixed Oligopoly, Privatization, and Strategic Trade Policy," Southern Economic Journal, Vol. 65, No. 2, April 1998, pp. 264-281.

[11] J. Poyago-Theotoky, "R\&D Competition in a Mixed Duopoly Under Uncertainty and Easy Imitation," Journal of Comparative Economics, Vol. 26, No. 3, September 1998, pp. 415-428.

[12] K. Fjell and J. S. Heywood, "Public Stackelberg Leadership in a Mixed Oligopoly with Foreign Firms," Australian Economic Papers, Vol. 41, No. 3, September 2002, pp. 267-281.

[13] T. Matsumura, "Stackelberg Mixed Duopoly with a Foreign Competitor," Bulletin of Economic Research, Vol. 55, No. 3, July 2003, pp. 275-287.

[14] L. Han and H. Ogawa, "Economic Integration and Strategic Privatization in an International Mixed Oligopoly," FinanzArchiv, Vol. 64, No. 3, September 2008, pp. 352363.

[15] K. Ohnishi, "International Mixed Duopoly and Strategic Commitments," International Economics and Economic Policy, Vol. 4, No. 4, February 2008, pp. 421-432.

[16] J. Fernández-Ruiz, "Managerial Delegation in a Mixed Duopoly with a Foreign Competitor," Economics Bulletin, Vol. 29, No. 1, February 2009, pp. 90-99.

[17] D. Bös, "Public Enterprise Economics," North-Holland,
1986.

[18] D. Bös, "Privatization: A Theoretical Treatment," Clarendon Press, 2001

[19] J. Vickers and G. Yarrow, "Privatization: An Economic Analysis," MIT Press, 1988.

[20] H. Cremer, M. Marchand and J.-F. Thisse, "The Public Firm as an Instrument for Regulating an Oligopolistic Market," Oxford Economic Papers, Vol. 41, No. 1, January 1989 , pp. 283-301.

[21] L. Nett, "Mixed Oligopoly with Homogeneous Goods," Annals of Public and Cooperative Economics, Vol. 64, No. 3, July 1993, pp. 367-393.

[22] D. Bös, "Income Taxation, Public Sector Pricing and Redistribution," Scandinavian Journal of Economics, Vol. 86, No. 2, June 1984, pp. 166-183.

[23] H. Cremer, M. Marchand and J.-F. Thisse, "Mixed Oligopoly with Differentiated Products," International Journal of Industrial Organization, Vol. 9, No. 1, March 1991, pp. 43-53.

[24] A. Ogawa and K. Kato, "Price Competition in a Mixed Duopoly," Economics Bulletin, Vol. 12, No. 4, July 2006, pp. 1-5.

[25] J. C. Bárcena-Ruiz, "Endogenous Timing in a Mixed Duopoly: Price Competition," Journal of Economics, Vol. 91, No. 3, July 2007, pp. 263-272.

[26] J. C. Barcena-Ruiz and M. B. Garzón, "Capacity Choice in a Mixed Duopoly under Price Competition," Economics Bulletin, Vol. 12, No. 26, October 2007, pp. 1-7.

[27] K. Ohnishi, "Domestic and International Mixed Models with Price Competition," International Review of Economics, Vol. 57, No. 1, March 2010, pp. 1-7. 